\title{
PROTECTED GEOGRAPHICAL INDICATION RECOGNITION AND WILLINGNESS TO PAY: A CASE OF GROJEC APPLE
}

\author{
Bruce L. Ahrendsen ${ }^{1}$ and Edward Majewski ${ }^{2}$ \\ ${ }^{1}$ Department of Agricultural Economics and Agribusiness, University of Arkansas Division of Agriculture, 217 \\ Agriculture Building, Fayetteville, Arkansas 72701 USA, ahrend@uark.edu \\ ${ }^{2}$ Department of Economics and Organisation of Management, Warsaw University of Life Sciences, \\ Nowoursynowska 166, 02-787 Warsaw, Poland, edward_majewski@sggw.pl
}

\begin{abstract}
The Grojec region of Poland is an important region for apple production and accounts for 40 percent of domestic apple production. Apple growers from the region made an attempt to strengthen their competitive position through registering their apples as Protected Geographical Indication (PGI) products. The European Commission's PGI allows food producers to obtain market recognition and a premium price for their products. Although the Grojec Apple received PGI registration in 2011, little has been done to promote apples with the PGI label. Two important research questions are addressed: 1) Does the Polish market recognize Grojec Apple PGI, and 2) Does the market value Grojec Apple PGI? Logit and regression models are estimated using survey data collected during an International MBA in Agribusiness and Commerce study week in Warsaw. Only 22\% of consumers recognize Grojec Apple PGI. Yet, 70\% of consumers indicate they are willing to pay more for the product and their average willingness to pay (WTP) premium is $32 \%$.

Results indicate use of the PGI label may be effective in improving sales and profit margins for Grojec Apple producers and their affiliated cooperatives. Older consumers are more likely to indicate a WTP premium. Males, smaller households, and consumers less sensitive to apple price indicate a higher WTP premium. An advertising campaign promoting Grojec Apple PGI as a better product may be effective at increasing consumer likelihood to pay more and WTP premium. Although "Grojec" is already familiar to most consumers in central Poland as a region for apples, a Grojec Apple with PGI label would assure consumers they are purchasing apples from the Grojec region and the apples are high quality.
\end{abstract}

Keywords: Poland, apple, willingness to pay, protected geographical indication, logit regression

(JEL Code: D12, Q13, Q18)

\section{INTRODUCTION}

The Grojec region of Poland is an important region for apple production and accounts for 40 percent of domestic apple production. A large portion of Polish apple production was exported to Russia until the Russian Federation decreed a ban on imports of agricultural products, including apples, from the European Union (EU), United States (US), and other countries on 6 August 2014. The Russian ban of agricultural products was in retaliation of Western economic sanctions placed on the Russian Federation for its annexation of the Crimea (Kraatz, 2014). Even prior to the ban, the Russian Federation placed an embargo on fruit and vegetable imports from Poland for sanitary reasons in late July 2014, which occurred only a few days after the EU and US placed financial and economic sanctions on Russia (Kraatz, 2014). Thus, a large share of the market for Polish apples was suddenly taken away.

Faced with such a situation, what market alternatives are there for Polish apple producers? An obvious response is to promote apples and grow market share in Poland and elsewhere in the EU and beyond. The EU's Protected Geographical Indication (PGI) is a way to obtain market recognition and a premium price for a product (European Commission, 2012). Although the Grojec region had received a PGI for the name "Jabłka Grójeckie" on 5 October 2011, little has been done to promote apples with the Grojec Apple PGI. This raises two important research questions undertaken in this article: 1) Does the Polish market recognize the Grojec Apple PGI product, and 2) Does the market value Grojec Apple as a PGI product?

Survey data were collected from 176 consumers at two supermarkets in Warsaw on 3 June 2016. Logit models are estimated to identify factors associated with: 1) the likelihood of recognizing the PGI registered product Grojec Apple, and 2) the likelihood of willing to pay more for the Grojec Apple with PGI. For consumers willing to pay more, a regression model is estimated to identify factors associated with how much more they are willing to pay.

The results and recommendations are expected to assist marketers of Grojec Apples and other PGI products develop a 
marketing plan to grow market share and profits. Although the Russian ban on agricultural product imports has resulted in an economic hardship for Polish apple producers, adjustments to their marketing plans may lead to improved economic results in the long run.

\section{GROJEC APPLES}

Poland is a leading producer of apples in the EU with a $26 \%$ share, and the fourth in the World at about $4 \%$ share, after China, United States, and Turkey (Agencja Rynku Rolnego, 2014). A dynamic increase of production of apples in the most recent period indicates a growing importance of the apple sector (Figure 1).

Such trend in the production is to some extent from the $9 \%$ rise in the area of apple orchards, but mainly the increase in production is from an increase in yields. On average, yield more than doubled from about 10 tonnes per ha in 2005 to about 20 tonnes per ha in 2016, which is due to technological advancements and growing harvests from newly planted apple trees. Yet, average yields of apples in Poland are relatively low, but this is because of fragmented farm structure of farms in Poland. Yields in small scale apple farms are usually much below the country average, but in specialized farms yields at the level 30-40 tonnes per hectare may be considered standard.

Along with the production increase, exports of Polish apples grew until 2013. However, there was a noticeable decline in the volume in Polish apple exports after a ban on imports of some goods to Russia from the EU area was introduced in August 2014. Russia was historically the main export market for Polish apples. Apple exports to Russia in the years 2012 and 2013 amounted to about $60 \%$ of total exports in terms of volume and value and fell to practically null following the Russian import ban.

The Grojec region, located $50 \mathrm{~km}$ south of Warsaw, the capital of Poland, is referred to in Poland as "the biggest orchard of Europe". The first plantations of apple trees were established in the Grojec region as early as the 16th century, of which apples were sent to the court of the Polish kings. Significant development of apple cultivation in this region was started in the late nineteenth century. At present, around $40 \%$ of apples in Poland are produced in the region.

Apples from this area are characterized by specific acidity, averaging 5\% higher than apples of the same variety from other regions. Another distinguishing feature of these fruits is the very strong blush resulting from the higher-also on average 5\% - colorants under the skin (mainly anthocyanins and carotenoids). The unique advantages of the grojeckie apples are due to the climatic and soil conditions. There is a special microclimate, characterized by low temperatures at night, in the period preceding fruit harvest. These factors affect the specific and expressive taste of apples.

Grojec Apples were entered in the EU Register as a PGI on 5 October 2011. Apple producers are required to follow Integrated Production (IP) or GLOBALGAP specifications (Association Grojec Orchards, 2017). Fulfilling all the requirements allows producers to sell apples with the PGI logo. PGI logo used as one of the promotion tools should increase the effectiveness of promotional activities and strengthen the position of Grojec apple producers in domestic and foreign markets.

\section{GEOGRAPHIC INDICATION OF PRODUCTS}

There are various methods for indicating products are specific to particular geographic areas or have a traditional character. For the EU, "Foodstuff products which have specific characteristics such as traditional production methods or characteristic attributable to a specific region may be granted the EU quality logo" (European Commission, 2017b). There are three indications in the EU: Protected Designation

Figure 1. Poland apple production and exports, 2000-2016

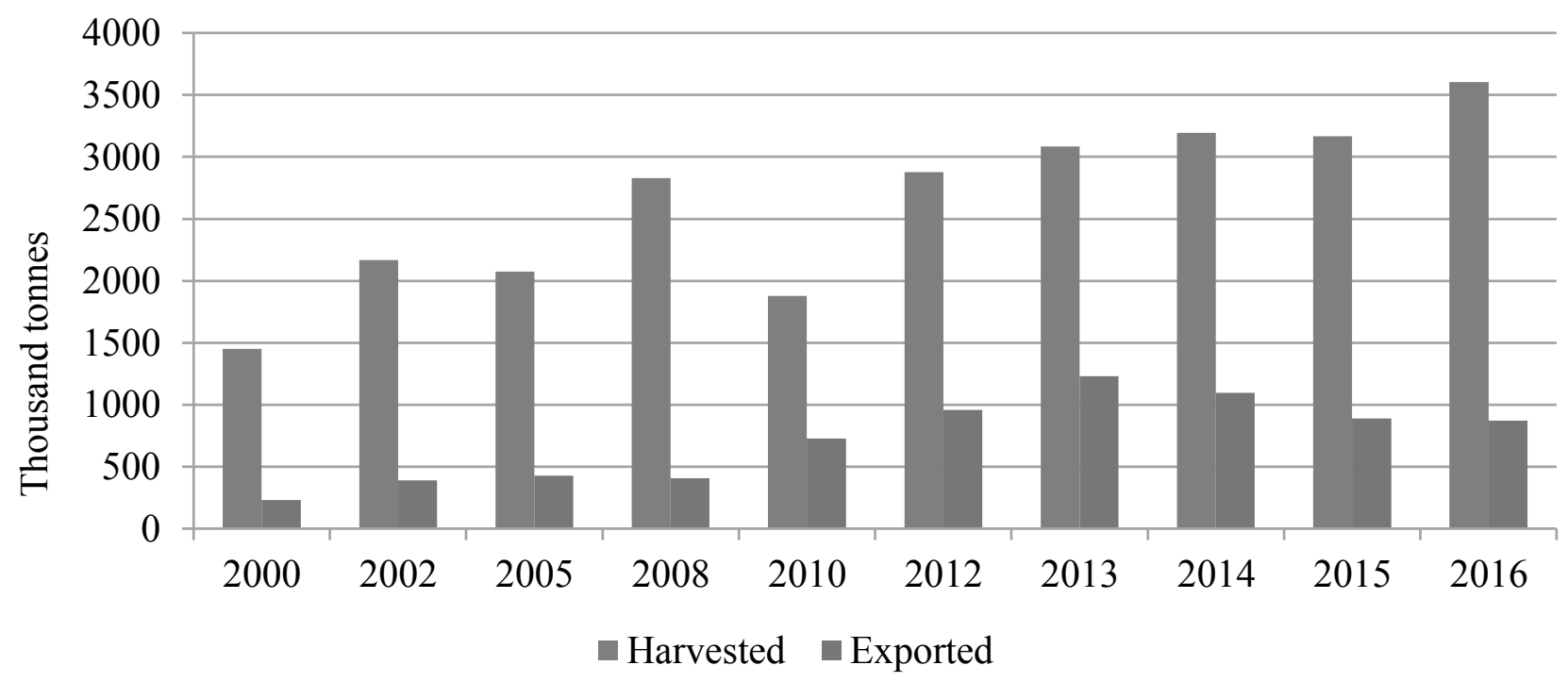

Source: Author calculations based on IERiGZ (2016) and Fresh-Market.pl (2017) 
of Origin (PDO), Protected Geographical Indication (PGI), and Traditional Specialty Guaranteed (TSG). These are intended to guarantee a particular foodstuff or agricultural product come from a specific region and/or follow a particular traditional production process.

PDO provides the strongest connection to the geographic territory by requiring all aspects of production, processing, and preparation originate from the region. As of 1 July 2017, there are 618 PDO registered products (45\%) out a total of 1377 registered products for the EU countries (European Commission, 2017a). Of these, 143 products (23\%) are in the "fruits, vegetables, and cereals, fresh or processed" category, which includes apples.

The PGI designation identifies products whose quality or reputation is linked to the place or region where it is produced, processed or prepared. However unlike PDO, the ingredients used in the production process of PGI products need not necessarily come from the geographical area. Within the EU countries, the majority of registered products are PGI with 703 (51\%). Among the PGI products, $220(31 \%)$ are in the category "fruits, vegetables, and cereals, fresh or processed". At only 56 (4\%), the TSG designation has the fewest number of registered products. TSG products have traditional character from either composition or means of production, although without a link to a particular geographic area.

Poland has 37 registered products (8 PDO, 20 PGI, and 9 TSG), which is relatively few when compared to 1377 for all EU countries. All six of the Polish products in the "fruits, vegetables, and cereals, fresh or processed" category are PGI, including Grojec Apples.

\section{BACKGROUND LITERATURE}

Bicskei (2014) provides an overview of studies on consumers' awareness of PGI and PDO in the EU. Estimates of consumer awareness varied from a low of 3\% to a high of $68 \%$. However, the author notes two studies with higher estimates should be expected to have higher awareness, since they focused on consumers of regional products that might be more likely to be aware of geographic indicators. Without the two studies, the estimates of awareness varied from $3 \%$ to $14 \%$. The author points out that the probability of recognizing geographic indicators is positively correlated with the number of EU registered geographic indicators in the study region. With such low levels of recognition, PGI and PGO are far behind other designations such as Fair Trade and Bio.

Deselnicu et al. (2013) give a review of geographical indication food valuation studies from around the world and conducts a meta-analysis of studies since the 1990s that estimate price premiums for agriculture products with a geographical indication. They note a price difference between a product with a geographic indicator and a similar product without the indicator is one measure of the indicator's success. Various methodologies have been used to estimate the price premium including hedonic, contingent valuation, and random utility models. As an example, Botonaki and Tsakiridou (2004) use a random utility model to estimate the consumers' willingness to pay for a Greek quality wine with a geographic indication label. They found for their Athens-based survey of consumers that $49 \%$ had heard of the particular geographic indication label and consumers were willing to pay a $20 \%$ premium on average for the product with a geographic indicator. The probability of willingness to pay was related to consumer age, education, family status, and confidence in the geographic indicator.

McCluskey et al. (2007) investigated the amount US consumers were willing to pay more for a Washington state Gala apple. They found consumers' willingness to pay (WTP) more was related to consumer age and age squared, employment status, household size, and subjective sensory attributes in considering an ideal apple.

More recent studies citing Deselnicu et al. (2013) include Bontemps, Bouamra-Mechemache, and Simioni (2013) and Garavaglia and Mariani (2015) among others. Bontemps, Bouamra-Mechemache, and Simioni (2013) found geographic indicators reduced the exiting risk of cheese firms in France implying a positive impact on sustained competitiveness and firm survival. Garavaglia and Mariani (2015) find the location of the consumer relative to area of production of the certified product impacts consumer WTP, such that a consumer located in the same area as the production has a lower WTP premium than a consumer located in a different area.

\section{METHODOLOGY}

The analysis seeks to answer the questions: does the Polish market recognize Grojec Apple PGI; and does the market value Grojec Apples as a PGI product? These are dichotomous choices, such that a binomial logistic (logit) model or cumulative normal (probit) model are appropriate for their analysis. Both models have bell shaped distributions, although the logistic tends to have heavier tails than the normal (Amemiya, 1981). Since many of the explanatory variables in the present study are binary, the data yielded are more likely to be represented by a distribution with larger tails. For this reason the logit model is selected instead of the probit model (Johnson et al., 2010), although the choice between the two models usually does not make much difference in most applications (Greene, 2012).

Two logit models are estimated to identify factors associated with: 1) the likelihood of recognizing the PGI product, and 2) the likelihood of willing to pay more for a premium apple with a PGI logo. Following Greene (2012), let $Y=1$ when the consumer recognizes PGI (or is willing to pay more) and $Y=0$ when the consumer does not recognize PGI (or is not willing to pay more). The logit model is:

$$
\begin{aligned}
& P\left(Y_{i}=1\right)=F\left(X_{i}, \beta\right)=\exp \left(X_{i}^{\prime} \beta\right) /\left(1+\exp \left(X^{\prime} \beta\right)\right) \\
& P\left(Y_{i}=0\right)=1-F\left(X_{i}, \beta\right)=1 /\left(1+\exp \left(X_{i}^{\prime} \beta\right)\right),
\end{aligned}
$$

where $\mathrm{P}\left(Y_{i}=1\right)$ is the probability the $i$ th consumer recognizes PGI (or is willing to pay more), $X_{i}$ is the $i$ th row of a matrix of explanatory variables that has dimension $n$ 
$\mathrm{x} k, \beta$ is a $k \mathrm{x} 1$ vector of parameter coefficients, $n$ is the number of consumers, and $k$ is the number of coefficients. $\mathrm{P} i$ is regressed on the explanatory variables $X_{i}$.

Coefficients of parameter estimates are interpreted as influencing the probability of recognizing PGI (or willingness to pay more). Coefficients with positive values increase the probability and coefficients with negative values decrease the probability. This is based on the logarithm of the probability ratio, $\log \left(\mathrm{P}_{i} /\left(1-\mathrm{P}_{i}\right)\right)$, i.e., the logs-odds ratio.

For those consumers willing to pay more for an apple with PGI, a regression model is estimated to identify factors associated with how much more they are willing to pay.

$$
\mathrm{y}_{\mathrm{i}}=\mathrm{W}_{\mathrm{i}}{ }^{\prime} \alpha+\varepsilon_{\mathrm{i}} \quad \varepsilon_{\mathrm{i}} \sim \mathrm{N}(0, \sigma 2)
$$

where $y_{i}$ is the percent more consumers are willing to pay given they are willing to pay more, $W_{i}$ is a vector of explanatory variables, and $\alpha$ is a vector of parameters coefficients. It is assumed error term $\varepsilon_{i}$ is normally distributed with mean zero and constant variance $\sigma 2$.

\section{DATA}

Survey data were collected from 176 consumers at two supermarkets in Warsaw on 3 June 2016. The survey was

Table 1. Variable definitions and summary statistics

\begin{tabular}{|c|c|c|c|c|c|}
\hline Variable & Definition & Mean & Std Dev & Min & Max \\
\hline RECOG_PGI & $\begin{array}{l}\text { Equals } 1 \text { if knows "Protected Geographical Indication" (PGI), } \\
0 \text { otherwise }\end{array}$ & 0.28 & 0.45 & 0 & 1 \\
\hline RECOG_GROJEC_PGI & $\begin{array}{l}\text { Equals } 1 \text { if heard of the product "Grojec Apple" with PGI, } 0 \\
\text { otherwise }\end{array}$ & 0.22 & 0.42 & 0 & 1 \\
\hline PAY_MORE & $\begin{array}{l}\text { Equals } 1 \text { if willing to pay more for premium apple with PGI } \\
\log 0,0 \text { otherwise }\end{array}$ & 0.70 & 0.46 & 0 & 1 \\
\hline WTP $^{\mathbf{a}}$ & $\begin{array}{l}\text { Amount more willing to pay for premium apple with PGI } \\
\text { logo, in percent }\end{array}$ & 22.43 & 38.14 & 0 & 400 \\
\hline AGE & Consumer age in years & 42.89 & 17.68 & 14 & 93 \\
\hline AGE_SQUARED & Consumer age squared & 2150 & 1746 & 196 & 8649 \\
\hline FEMALE & Equals 1 if female, 0 otherwise & 0.66 & 0.48 & 0 & 1 \\
\hline HSEHOLD_NUMBER & Number of people in consumer's household & 2.53 & 1.25 & 1 & 6 \\
\hline I_PRICE & $\begin{array}{l}\text { Price importance equals: } 1 \text { very unimportant, } 2 \text { unimportant, } \\
3 \text { neither unimportant nor important, } 4 \text { important, } 5 \text { very } \\
\text { important }\end{array}$ & 3.10 & 1.53 & 1 & 5 \\
\hline SHOP_SUPERMKT & $\begin{array}{l}\text { Share of total apple purchases made at supermarkets/ } \\
\text { hypermarkets, in percent }\end{array}$ & 47.17 & 42.73 & 0 & 100 \\
\hline ONLINE & $\begin{array}{l}\text { Equals } 1 \text { if would like to order goods online and pick up at the } \\
\text { market, } 0 \text { otherwise }\end{array}$ & 0.35 & 0.48 & 0 & 1 \\
\hline BETTER & $\begin{array}{l}\text { Equals } 1 \text { if indicated Grojec Apple with PGI logo is } \\
\text { associated with better characteristic (luxury, exceptional taste, } \\
\text { outstanding, or high quality) than other apples, } 0 \text { otherwise }\end{array}$ & 0.85 & 0.36 & 0 & 1 \\
\hline INTERACT_ADVERT & $\begin{array}{l}\text { Equals } 1 \text { if indicated advertising involving personal interaction } \\
\text { (stands in markets/fairs, barbeque in orchard, brand } \\
\text { representative) is best for them, } 0 \text { otherwise }\end{array}$ & 0.64 & 0.48 & 0 & 1 \\
\hline MALL & $\begin{array}{l}\text { Equals } 1 \text { if survey was at shopping Mall store location, } 0 \\
\text { otherwise }\end{array}$ & 0.33 & 0.47 & 0 & 1 \\
\hline \multicolumn{6}{|c|}{$\mathrm{n}=176$, number of consumers surveyed on 3 June 2016 at two supermarkets in Warsaw, Poland } \\
\hline
\end{tabular}

Note: Right axis is average response to the importance of each characteristic, where 1 is very unimportant, 2 is unimportant, 3 is neither unimportant nor important, 4 is important, and 5 is very important.

Source: Survey data, Warsaw, Poland, 2016 
Figure 2. Importance of characteristics when purchasing apples

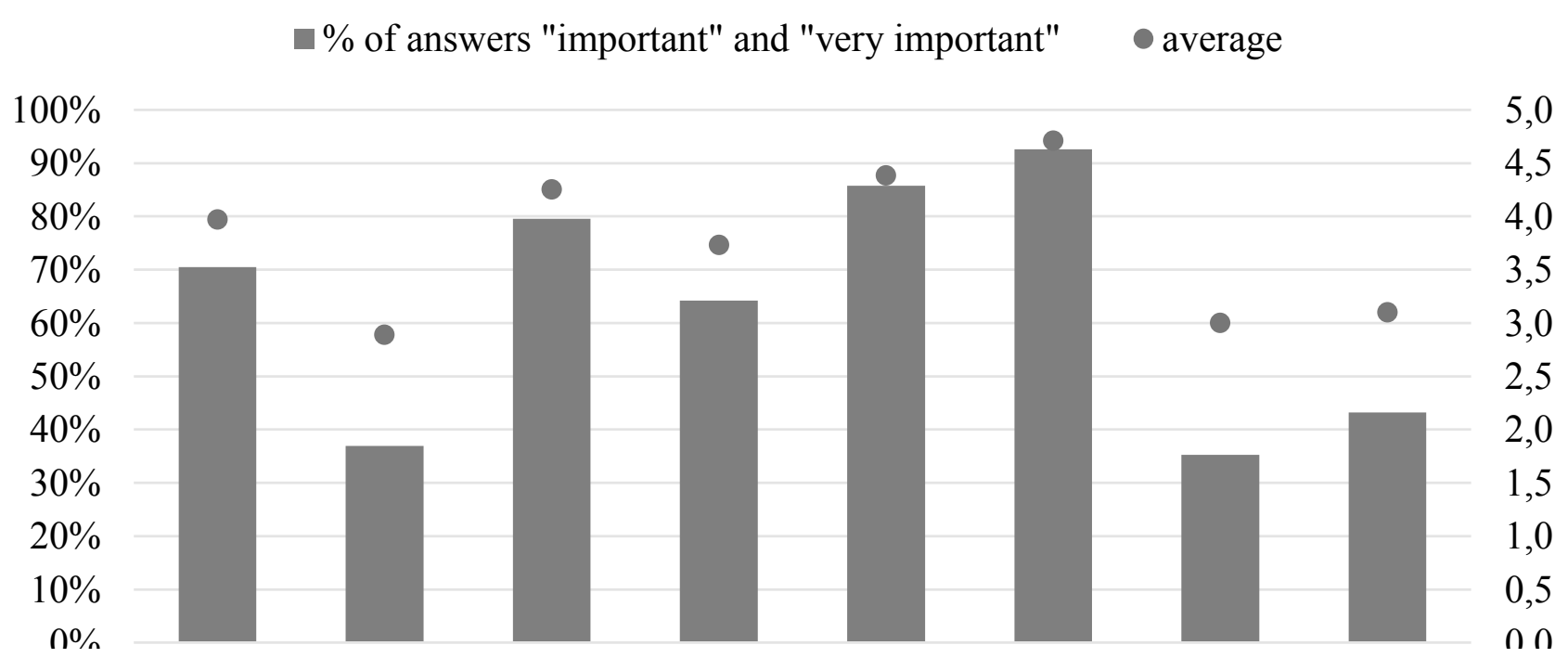

initiated as part of a case study during the International MBA in Agribusiness and Commercel study week held at the Warsaw University of Life Sciences. The survey consisted of questions related to the consumer's impression of "Grojec", recognitions of PGI label and Grojec Apple with PGI label, willingness to pay for Grojec Apple, personal shopping characteristics, and importance of various apple characteristics as well as demographics, such as gender, age, and number of household members.

The average age of consumers in the survey is 43 and $66 \%$ are female (Table 1). The average number of members in a consumer's household is 2.5. Consumers were asked about the importance of various apple characteristics when purchasing an apple. Taste of the apple is the most important characteristic on average, followed by apple firmness, variety, country of origin, color, price, size, and region of origin (Figure 2). Variety, color, firmness, taste, and size are sensory variables that are unique to the apple, whereas country and region appeals to a consumer's sense of place, and price is an economic variable.

The consumers were asked about the share of apples they purchased at different types of stores. The largest share of apple purchases by consumers are at supermarkets/ hypermarkets (47\%), followed by farmers' markets/bazaars (40\%) and local/small shops (12\%). At 35\%, a large share of consumers indicated they would like to order goods online (ONLINE) and pick them up at the store.

The data indicate the vast majority $(88 \%)$ of consumers associate the word "Grojec" with apples, fruit orchards, and pears, and the association with apples dominates for $68 \%$ of consumers. Among the consumers, $28 \%$ indicated they know what PGI is (RECOG_PGI). In particular to the

1 For more information about the International MBA in Agribusiness and Commerce and the AGRIMBA Network, see http://agrimba.net/.
Grojec Apple with PGI, 22\% of the consumers had heard about the product (RECOG_PGI_GROJEC). These levels of recognition are not necessarily low since other studies have found lower levels of geographical indicator recognition (Bicskei, 2014). Moreover, the recognition levels are not low considering Poland has relatively few indicators with 37 PDO, PGI, and TSG registered products when compared to other EU countries, and there is generally a positive correlation between number of indicators present in the country and indicator recognition (Bicskei, 2014).

All consumers received a definition and explanation of PGI after they responded to the question on recognition of PGI. Consumers were then asked if they are willing to pay more for a premium apple if it is labeled with a PGI logo (PAY MORE), and $70 \%$ of the consumers indicated they are willing to pay more. For the consumers who responded they are willing to pay more, they were asked how much more in percent they would be willing to pay (WTP premium). The data indicates those willing to pay more are willing to pay $32 \%$ more than the regular price on average. Deselnicu et al. (2013) found an average WTP premium of $15 \%$, although only a little more than half of the studies in their sample were based on European consumers and only 9\% had PGI certifications. When they limited their sample to only studies on European consumers, they found the PDO percentage premium was higher than the average PGI percentage premium. They also found produce and olive oil studies based on European consumers have an insignificant WTP premium relative to wine studies, whereas grain, meat, and cheese studies had statistically significant WTP premiums.

Consumers were asked about what characteristic they associate with a Grojec Apple with PGI label. The majority (85\%) of consumers thought a Grojec Apple with PGI label as being a better apple because they associated it with high quality (40\%), being outstanding (20\%), having exceptional taste (14\%), or being luxurious (11\%). Only $15 \%$ of consumers 
Table 2. Coefficient estimates and significance

\begin{tabular}{|c|c|c|c|c|c|c|}
\hline & & & \multicolumn{2}{|c|}{ Dependent variable } & & \\
\hline & \multicolumn{2}{|c|}{ RECOG_GROJEC_PGI } & \multicolumn{2}{|c|}{ PAY_MORE } & \multicolumn{2}{|c|}{ Log WTP } \\
\hline Independent variable & \multicolumn{2}{|c|}{ Coefficient estimates } & \multicolumn{2}{|c|}{ Coefficient estimates } & \multicolumn{2}{|c|}{ Coef. estimates } \\
\hline RECOG_PGI & 1.043 & $* *$ & & & & \\
\hline RECOG_GROJEC_PGI & & & 0.224 & & -1.617 & $* * *$ \\
\hline AGE & 0.069 & & 0.097 & $* *$ & 0.018 & \\
\hline AGE_SQUARED & -0.001 & & -0.001 & $*$ & 0.000 & \\
\hline FEMALE & 0.330 & & -0.393 & & -1.113 & $* * *$ \\
\hline HSEHOLD_NUMBER & -0.048 & & -0.063 & & -1.024 & $* * *$ \\
\hline I_PRICE & -0.036 & & -0.046 & & -0.185 & ** \\
\hline SHOP_SUPERMKT & 0.005 & & -0.002 & & 0.000 & \\
\hline ONLINE & 1.080 & $* *$ & 0.701 & * & -0.563 & \\
\hline BETTER & & & 1.568 & $* * *$ & 1.123 & $* * *$ \\
\hline INTERACT_ADVERT & 0.884 & $*$ & -0.245 & & -0.449 & \\
\hline MALL & -0.623 & & -0.637 & $*$ & -0.896 & ** \\
\hline Constant & -4.463 & $* * *$ & -1.950 & & 5.779 & $* * *$ \\
\hline $\mathrm{n}$ & 176 & & 176 & & 124 & \\
\hline
\end{tabular}

thought a Grojec Apple with PGI label is comparable to other apples. Most consumers (64\%) indicated advertising involving personal interaction, such as stands at supermarkets and fairs, barbeques with apple tasting at orchard, and meeting a brand representative, would be more effective on them than passive advertising, such as television, press/internet, and billboards/ posters.

\section{RESULTS}

The estimated logit and regression models coefficients are displayed in Table 2. All models are estimated by maximum likelihood using SAS 9.4 software.

\section{Recognize Grojec Apple with PGI}

The logit equation estimating whether a consumer recognizes Grojec Apple with PGI label (RECOG GROJEC PGI) has three significant explanatory variables not counting the constant term. As expected, consumers who know about PGI products are more likely to know about the product Grojec Apple with PGI label. This result implies Grojec Apple product recognition may improve and Grojec Apple producers and affiliated producer cooperatives may benefit, as well as producers of other PGI and PDO registered products, if there was better awareness and understanding of PGI and PDO labels. Consumers who want to purchase products online and pick them up at the store are more likely to know about Grojec Apple with PGI than other consumers. This may mean online consumers are more interested in purchasing Grojec Apple with PGI. Consumers who believe interactive advertising is more effective for them are more likely to know about the Grojec Apple with PGI than are consumers who believe passive advertising is effective. Efforts to better promote the Grojec Apple may be best spent through advertising by utilizing product stands at markets and food fairs and encouraging consumer visits to orchards.

\section{Willingness to pay more}

The logit model for the likelihood of consumer willingness to pay more (PAY_MORE) has five significant explanatory variables. AGE and AGE_SQUARED have positive and negative signs, respectively. The likelihood of willingness to pay more increases with consumer age, but at a decreasing rate as indicated by the negative sign on AGE_SQUARED. Consumers interested in shopping online and picking up at the store are more likely to be willing to pay more. Although the ONLINE variable is about general shopping, it may be even more important to have a PGI registration for produce items. The PGI may give consumers confidence the product will meet their expectations and standards for quality when they pick up the product at the store. The positive sign on the BETTER coefficient is expected. Consumers who associate better apple characteristics with a Grojec Apple with PGI label are more likely to be willing to pay more. Finally, consumers shopping at the mall location of the supermarket are less likely to be willing to pay more than those shopping at its stand-alone location.

\section{Willingness to pay premium}

A regression model is estimated to identify factors associated with the WTP premium a consumer is willing to pay for a Grojec Apple with PGI label provided the consumer indicated they would be willing to pay more. The 
WTP premium is measured in percent. However, since the distribution of the WTP premium is highly skewed to the right, the dependent variable is the log of the WTP premium.

The regression results reveal six significant explanatory variables, excluding the constant term, affect the WTP premium. Most of the estimated coefficients have negative signs. These negative signs should be interpreted as a willingness to pay a lesser amount more, i.e., a lower WTP premium, since all of the observations in the regression sample indicated a willingness to pay more. Consumers who recognize Grojec Apple with PGI label have a positive WTP premium, although the premium is less than consumers who do not recognize the product. This is somewhat surprising, although not unexpected. The means of the WTP premiums for consumers recognizing and not recognizing Grojec Apple with PGI are $26 \%$ and $34 \%$ respectively. This result may be somewhat related to the result found by Garavaglia and Mariani (2015). They found location impacts consumer WTP premium, such that a consumer located in the same area as the production has a lower WTP premium than a consumer located in a different area. They attribute the result to differences in the information set of consumers. Although consumer place of residence is unknown and all consumers are presented with PGI information in the study presented here, consumers familiar with Grojec Apple may have more experience, i.e., information, with Grojec Apple which could impact their decision to have a lower WTP premium.

FEMALE is negative meaning female consumers have a lower WTP premium than male consumers. For household number, the WTP premium decreases as there are more members in the household. Larger households are more likely to have budget constraints that would limit their ability to pay more. The importance of apple price in consumers purchase decision is negatively related to WTP premium, such that the WTP premium decreases as apple price importance increases. These consumers are more price sensitive and, thus, their WTP premium is less. As expected, consumers who associate better apple characteristics with a Grojec Apple with PGI label have a higher WTP premium than consumers who believe the apple is similar to other apples. Consumers shopping at the mall location of the supermarket have a lower WTP premium than consumers shopping at the stand-alone location.

\section{CONCLUSIONS}

Logit models were estimated using survey data to identify factors associated with: 1) the likelihood consumers recognize the PGI registered product Grojec Apple, and 2) the likelihood of willing to pay more for the Grojec Apple with PGI. For consumers willing to more, a regression model was estimated to identify factors associated with their WTP premium. Only 22\% of the consumers recognized Grojec Apple with PGI. Yet, $70 \%$ of consumers indicated they would be willing to pay more. And for those consumers willing to pay more, the average premium they are willing to pay was $32 \%$.

The results of the analysis revealed a number of factors associated with the likelihoods of recognition and willingness to pay more for Grojec Apple with PGI by consumers. Use of the PGI label may be effective in improving sales and profit margins for Grojec Apple producers and their affiliated cooperatives. Older consumers are more likely to be willing to pay a premium, although not necessarily a higher WTP premium than younger consumers. For consumers willing to pay more, females, larger households, and consumers more sensitive to apple price pay less of a WTP premium than males, smaller households, and consumers less sensitive to apple price.

An advertising campaign that shows Grojec Apple with PGI to be a better product may be effective at increasing consumers' likelihood to pay more and paying a higher premium for the product. Although "Grojec" is already familiar to most consumers in central Poland as a region of orchards and apples, a Grojec Apple with PGI label would assure consumers they are purchasing apples from the Grojec region and the apples are high quality.

Ideally a larger number of consumers and measures of consumer education and household income would have been included in the survey. However, the data are quite good considering the survey design and data collection occurred during one day of an International MBA in Agribusiness and Commerce study week.

\section{ACKNOWLEDGEMENTS}

The authors gratefully acknowledge the support of the Dean of Economic Sciences at the Warsaw University of Life Sciences (WULS), the "Apple" team of Aleksandra Fraj, Mykhailo Bilaniuk, Thao Trinh, Joanna Kozak, Filip Frątczak, Martyna Piotrowska, and Olga Wielgołaska who participated in the 2016 study week of the International MBA in Agribusiness and Commerce at WULS, and the assistance of Dr. Heather Price.

This work was supported, in part, by the USDA National Institute of Food and Agriculture, Hatch/Multistate project 1005079. However, any opinions, findings, conclusions, or recommendations expressed in this publication are those of the authors and do not necessarily reflect the view of the U.S. Department of Agriculture, University of Arkansas, or Warsaw University of Life Sciences.

\section{REFERENCES}

Amemiya, T. (1981): Qualitative response models: a survey. Journal of Economic Literature, 19(1):1483-1536.

Agencja Rynku Rolnego. (2014): Rynek owoców w Polsce (Fruit market in Poland). Agricultural Market Agency, Warsaw, Poland, ISBN 978-83-64002-51-9, accessed January 292018 at: http:// www.kowr.gov.pl/uploads/rynek-owocow2014-pl.pdf.

Association Grojec Orchards. (2017): Jabłka grójeckie, accessed July 172017 at: http://www.trzyznakismaku.pl/produkty/jablkagrojeckie.

Bicskei, M. (2014): Are protected designation of origin and geographical indication distinguished by consumers? an overview and synthesis of empirical evidence. In Social identity in the provi- 
sion and protection of cultural goods, $\mathrm{PhD}$, Faculty of Economics, University of Göttingen, Göttingen, Germany, pp. 48-62, accessed July 172017 at: https://ediss.uni-goettingen.de/bitstream/ handle/11858/00-1735-0000-0022-5DCB-F/Bicskei Dissertation_2014.12.19.pdf? sequence $=1 \#$ page $=52$.

Bontemps C, Bouamra-Mechemache Z, Simioni M. (2013): Quality labels and firm survival: some first empirical evidence. European Review of Agricultural Economics, July 1; 40(3):413-439, DOI: doi.org/10.1093/erae/jbs034.

Botonaki, A, Tsakiridou E. (2004): Consumer response evaluation of a Greek quality wine. Acta Agriculturae Scandinavica, Section C - Food Economics, June; 1(2):91-98, DOI: 10.1080/16507540410024515.

Deselnicu OC, Costanigro M, Souza-Monteiro DM, McFadden DT. (2013): A meta-analysis of geographical indication food valuation studies: what drives the premium for origin-based labels. Journal of Agricultural and Resource Economics, 38(2):204-219, accessed July 142017 at: http://purl.umn.edu/158285.

European Commission. (2012): Introduction - EU agricultural product quality policy. Executive Agency for Health and Consumers, Better Training for Safer Food, slide 11, accessed February 262017.

European Commission. (2017a): Database of origin and registration (DOOR). Agriculture and Rural Development, accessed July 142017 at: http://ec.europa.eu/agriculture/quality/door/list.html;js essionid=pL0hLqqLXhNmFQyFl1b24mY3t9dJQPflg3xbL2YphG T4k6zdWn34\%21-370879141.

European Commission. (2017b): Quality policy: foodstuff and agricultural products. Agriculture and Rural Development, accessed July 14 2017: https://ec.europa.eu/agriculture/quality/schemes/ foodstuff_en.

Fresh-market pl. (2017): Export of apples from Poland. Various issues, accessed July 172017 at: http://www.fresh-market.pl// eksport jablek z polski w 2016 roku,p1969493902 and http:// www.fresh-market.pl/owoce_i_warzywa/owoce/jablka/eksport jablek_z_polski_w_2014_roku,p72109316.
Garavaglia C, Mariani P. (2015): How much do consumers value PDO certifications? estimates of WTP for PDO dry-cured ham in Italy. In 145th Seminar, April 14-15, 2015, Parma, Italy Apr (No. 200376), European Association of Agricultural Economists, accessed July 172017 at AgEcon Search: http://purl.umn. edu/200376.

Greene, WH. (2012): Econometric analysis. 7th ed. Upper Saddle River, New Jersey: Prentice Hall.

IERiGZ (2016): Rynek owocow i warzyw - stan i perspektywy (Fruit and vegetables market - status and prospects). Ministry of Agriculture and Rural Development, Institute of Agricultural Economics and Food Economy, Warsaw, Poland, December, Issue 49, ISSN 1231-2584.

Johnson RJ, Doye D, Lalman DL, Peel DS, Raper KC, Chung C. (2010): Factors affecting adoption of recommended management practices in stocker cattle production. Journal of Agricultural and Applied Economics, February; 42(1):15-30, accessed July 172017 at: https://ageconsearch.umn.edu/bitstream/57153/2/jaae223.pdf.

Kraatz, S. (2014): The Russian embargo: impact on the economic and employment situation in the EU. European Parliament, Employment and Social Affairs Briefing, PE 536.291, October, pp. 1-10, accessed February 262017 at: http://www.europarl.europa. eu/RegData/etudes/BRIE/2014/536291/IPOL_BRI(2014)536291_ EN.pdf.

McCluskey JJ, Mittelhammer RC, Marin AB, Wright KS. (2007): Effect of quality characteristics on consumers' willingness to pay for Gala apples. Canadian Journal of Agricultural Economics, June; 55(2):217-231, DOI: 10.1111/j.1744-7976.2007.00089.x. 